can's $t$ tests were used for specific post hoc compari sons.

10. S. Levine, S. G. Wiener, C. L. Coe, F. E. S. Bayart, K. T. Hayashi, Child Dev. 58, 1408 (1987)

11. T. F. Rowell and R. A. Hinde, Proc. Zool. Soc. Lond. 138, 279 (1962).

12. R. C. Bolles, Psychol. Rev. 77, 32 (1970)

13. R. B. Blanchard, K. K. Fukunaga, D. C. Blanchard, Bull. Psychon. Soc. 8, 179 (1976); G. G. Gallup and S. D. Suarez, Anim. Behav. 28, 368 (1976); I. EibleEibesfeldt, in Brain Mechanisms and Leaming, E. A. Fessard, R. W. Gerard, J. Konorski, Eds. (Blackwell Scientific, Oxford, 1961), pp. 53-73; E. Curio, The Ethology of Predation (Springer-Verlag, New York, 1976).

14. J. Kagan, J. S. Reznick, N. S. Snidman, Child Dev 58, 1459 (1987); Science 240, 167 (1988).
15. J. Panksepp, B. Herman, R. Conner, P. Bishop, J. P. Scott, Biol. Psychiatry 13, 607 (1976).

16. N. H. Kalin, S. E. Shelton, C. M. Barksdale, Brain Res. 440, 285 (1988).

17. In all of the pharmacologic studies reported in this paper, the effects of a single dose of drug were compared with those of vehicle. The dose selected was based on complete dose-response studies in infant monkeys performed earlier $(16,18)$. The same 12 subjects were used over a 2 -month period for the morphine, naloxone, and diazepam studies. At the beginning of these studies the infants ranged in age from 9 to 12 months.

18. N. H. Kalin et al., Brain Res. 408, 192 (1987).

19. Preliminary experiments showed that diazepam decreases vocalizations induced by separation in infant rhesus monkeys. This effect was probably not medi- ated by diazepam's interaction with benzodiazepine receptors because pretreatment with the benzodiazepine antagonist Ro 15-1788 did not block it. In fact, lower doses of diazepam increased activity levels, an effect that was reversed by pretreatment with the benzodiazepine antagonist.

20. D. C. Blanchard and R. J. Blanchard, Annu. Rev. Psychol. 39, 43 (1988)

21. Supported by the Veterans Administration Medical Research Service and by NIH grant DK-35641. The authors gratefully acknowledge the support of the Wisconsin Regional Primate Center and the Harlow Primate Laboratory, as well as the technical assistance of H. Van Valkenberg, V. Schneider, and K. Renk and the editorial assistance of C. Steinhart.

17 November 1988; accepted 7 February 1989

\section{Ethanol Inhibits NMDA-Activated Ion Current in Hippocampal Neurons}

David M. Lovinger, ${ }^{*}$ Geoffrey White, Forrest F. Weight

The ion current induced by the glutamate receptor agonist $N$-methyl-D-aspartate (NMDA) in voltage-clamped hippocampal neurons was inhibited by ethanol (EtOH). Inhibition increased in a concentration-dependent manner over the range 5 to $50 \mathrm{mM}$, a range that also produces intoxication. The amplitude of the NMDA-activated current was reduced 61 percent by $50 \mathrm{mM}$ EtOH; in contrast, this concentration of EtOH reduced the amplitude of current activated by the glutamate receptor agonists kainate and quisqualate by only 18 and 15 percent, respectively. The potency for inhibition of the NMDA-activated current by several alcohols is linearly related to their intoxicating potency, suggesting that alcohol-induced inhibition of responses to NMDA receptor activation may contribute to the neural and cognitive impairments associated with intoxication.

A LTHOUGH THE COGNITIVE AND BEhavioral manifestations of $\mathrm{EtOH}$ intoxication are well known, the cellular and molecular mechanisms through which $\mathrm{EtOH}$ produces its actions are poorly understood. Electrophysiological experiments have shown that EtOH can alter the firing rate or excitability of several types of central nervous system (CNS) neurons (1); however, voltage-clamp experiments on mammalian neurons have not revealed a specific membrane ion current that is affected by intoxicating concentrations of $\mathrm{EtOH}$.

Ethanol could produce its effects by altering neural excitation. Glutamate appears to be the major excitatory neurotransmitter in the mammalian CNS (2). Glutamate produces its excitatory action through the activation of at least three receptor subtypes distinguished on the basis of their response to the agonists kainate, quisqualate, and $N$ methyl-D-aspartate (2). The NMDA receptor is thought to be involved in excitatory neural phenomena (3), neural plasticity (4), cognitive function (5), and certain forms of behavior (6). Kainate and quisqualate receptors, on the other hand, appear to mediate fast excitatory synaptic transmission (7).

We have examined the effect of $\mathrm{EtOH}$ on ion currents activated by glutamate receptor agonists in voltage-clamped hippocampal neurons (8). The effect of $\mathrm{EtOH}$ on the ion currents induced by the application of NMDA, kainate, and quisqualate in voltageclamped hippocampal neurons (9) is illustrated in Fig. 1. The amplitude of the NMDA-activated current was greatly reduced in the presence of $50 \mathrm{mM}$ EtOH (Fig. 1A). Over the concentration range 5 to 100 $\mathrm{mM}$, EtOH inhibited the response to NMDA. The average inhibition by $50 \mathrm{mM}$ EtOH was $61 \pm 3 \%(n=14)$, and the concentration that produced $50 \%$ inhibition $\left(\mathrm{IC}_{50}\right)$ was $\sim 30 \mathrm{mM}(10)$. (Reported values are mean \pm SEM.) The average inhibition produced by $100 \mathrm{mM} \mathrm{EtOH}$ was $69 \pm 6 \%$ $(n=5)$, which was not significantly greater than the inhibition by $50 \mathrm{mM}$ EtOH $(P>0.10$, unpaired $t$ test). Inhibition of the NMDA-activated current was not observed with $2.5 \mathrm{mM} \mathrm{EtOH}$; however, in some neurons this concentration increased current amplitude. The percent reduction of kainate- and quisqualate-activated current amplitude by $50 \mathrm{~m} M \mathrm{EtOH}$ was considerably less than the reduction of NMDA-induced current amplitude at the same $\mathrm{EtOH}$ concentration (compare Fig. 1, B and C, to Fig. 1A). The average inhibition by $50 \mathrm{mM}$ EtOH of the kainate-activated current was $18 \pm 2 \%$ $(n=5)$ and of the quisqualate-activated current was $18 \pm 2 \%(n=5)$ and of the quisqualate-activated current was $15 \pm 2 \%$ $(n=5)$. EtOH was less potent in inhibiting kainate- and quisqualate-activated currents than in inhibiting the NMDA-induced current over a range of $\mathrm{EtOH}$ concentrations (Fig. 1, B and C).

Because different alcohols have different potencies for producing intoxication (1113), we examined the effect of several alcohols on the NMDA-activated current. Methanol $(200 \mathrm{mM})$ (Fig. 2A), 1-butanol (10 $\mathrm{mM}$ ) (Fig. 2B), and isopentanol (0.5 $\mathrm{mM}$ ) (Fig. 2C) produced an inhibition of the NMDA-activated current comparable to the inhibition by $50 \mathrm{mM}$ EtOH (Fig. 1A). These data suggest that the alcohols differ in their potency for inhibiting the response to NMDA. The potency of the alcohols for inhibiting the NMDA-activated current was further evaluated by examining the effect of different concentrations of each of the three alcohols on the response to NMDA. Inhibition of the NMDA-activated current increased with increasing concentrations of each alcohol, but the threshold for inhibition and the IC $_{50}$ differed among the alcohols (Fig. 2). Methanol (Fig. 2A) was less potent than $\mathrm{EtOH}$ in inhibiting the NMDA-activated current (compare to Fig. 1A). The threshold for methanol inhibition was $\sim 25 \mathrm{mM}$ and the $\mathrm{IC}_{50}$ was $\sim 117 \mathrm{mM}$. Both 1-butanol and isopentanol were more potent than $\mathrm{EtOH}$ in their inhibition of the NMDA-activated current. The threshold for 1-butanol (Fig. 2B) inhibition was $\sim 0.01$ $\mathrm{m} M$ and the $\mathrm{IC}_{50}$ was $\sim 1.14 \mathrm{mM}$. Isopentanol (Fig. 2C) was the most potent of the four alcohols tested, inhibiting the response to NMDA with a threshold of $\sim 0.001 \mathrm{mM}$ and an $\mathrm{IC}_{50}$ of $\sim 0.32 \mathrm{mM}$.

Section of Electrophysiology, Laboratory of Physiologic and Pharmacologic Studies, National Institute on Alcohol Abuse and Alcoholism, Rockville, MD 20852.

*To whom correspondence should be addressed at Section of Electrophysiology, NIAAA, 12501 Washington Avenue, Rockville, MD 20852. 
Because the alcohols exhibit different degrees of hydrophobicity $(11,12)$, our observations raised the question of whether the potency of different alcohols for inhibition of the NMDA-activated current might be related to their hydrophobicity. The $\mathrm{IC}_{50}$ for inhibition of the response to NMDA de- creases as the alcohol hydrophobicity increases (Fig. 3A) (12). Moreover, there is a significant linear relation between these two measures, suggesting that the potency with which alcohols inhibit the NMDA-induced current increases as a function of increasing hydrophobicity.
A

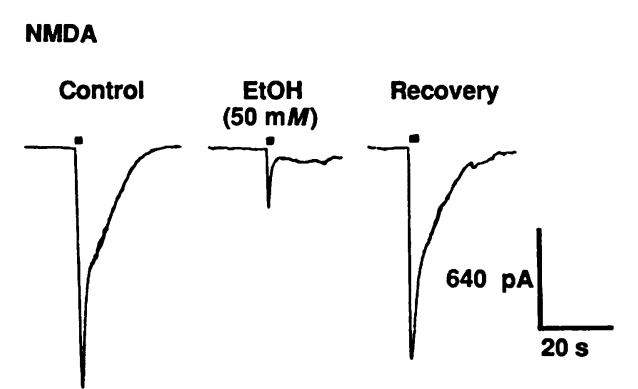

B

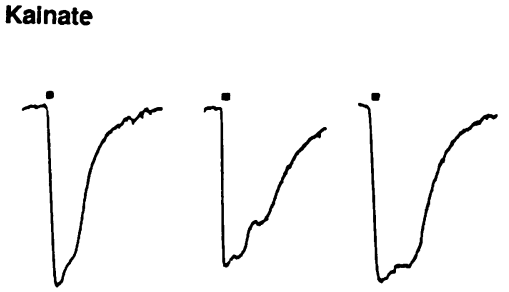

C

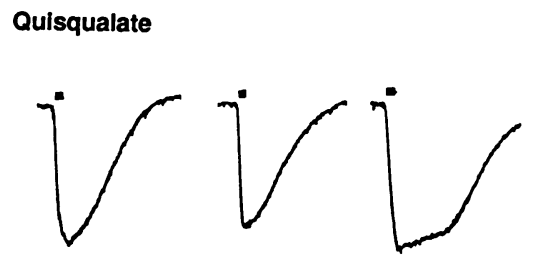

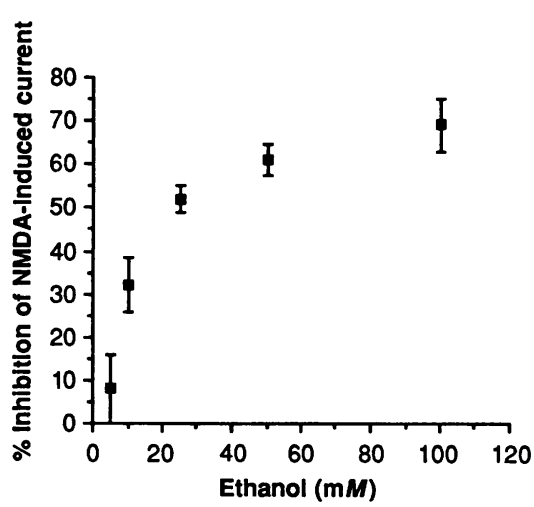
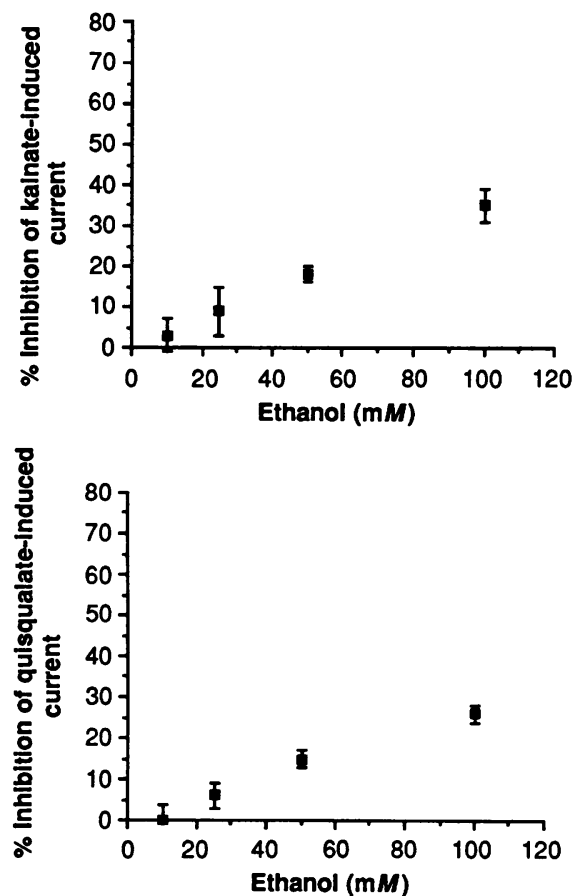

Fig. 1. EtOH effects on excitatory amino acid-induced ion currents in hippocampal neurons. (A) (Left) Effect of $50 \mathrm{mM}$ EtOH on current elicited by application of NMDA. (Control) Inward current induced by application of $50 \mu M$ NMDA. (EtOH) Response to $50 \mu M$ NMDA in the presence of $50 \mathrm{mM}$ EtOH. (Recovery) Current induced by $50 \mu M$ NMDA alone (in the absence of EtOH), 2 min after termination of $\mathrm{EtOH}$ application. (Right) Average percent inhibition of NMDA-activated current as a function of EtOH concentration. (B) (Left) Effect of $50 \mathrm{mM}$ EtOH on current elicited by application of kainate. The three records show inward current induced by application of $10 \mu M$ kainate before, during, and $2 \mathrm{~min}$ after the application of $50 \mathrm{mM} \mathrm{EtOH}$. (Right) Average percent inhibition of kainateactivated current as a function of EtOH concentration. (C) (Left) Effect of $50 \mathrm{mM}$ EtOH on current elicited by quisqualate application. The three records show inward current induced by application of 1 $\mu M$ quisqualate before, during, and $2 \mathrm{~min}$ after application of $50 \mathrm{mM}$ EtOH. (Right) Average percent inhibition of quisqualate-induced current as a function of $\mathrm{EtOH}$ concentration. The concentrations of the different agonists used produced currents of comparable amplitude in the absence of EtOH. Records in (A), (B), and (C) are taken from different neurons. Experiments examining NMDAactivated currents in hippocampal neurons were performed in extracellular medium containing no added $\mathrm{Mg}^{2+}$. The records in (B) and (C) were collected in the presence of concentrations of $\mathrm{Mg}^{2+}(1 \mathrm{mM})$ and APV $(50 \mu M)$ sufficient to prevent any contribution of NMDA receptor-activated currents to the currents induced by kainate and quisqualate. All records were taken at a membrane potential of -50 $\mathrm{mV}$. The solid bar above each record denotes time of drug application. Time and current calibrations in (A) apply to all records. Each point in the graphs represents the mean \pm SEM percent inhibition observed in at least four neurons tested at the indicated $\mathrm{EtOH}$ concentration.

Different alcohols also differ in their potency for producing intoxication (11-13), and thus we determined the relation between the potency of different alcohols for producing intoxication and their potency for inhibition of the NMDA-induced ion current. The $\mathrm{IC}_{50}$ values of the different alcohols for inhibition of the NMDA-induced current as a function of previously determined ED3 values (the dose of alcohol producing ataxia 2) for intoxication by the different alcohols are shown in Fig. 3B (12). The graph illustrates a significant linear relation between these two measures, suggesting that the more potent the alcohol is in inhibiting the NMDA-induced current the greater its potency for producing intoxication.

In the concentration range we examined ( 5 to $100 \mathrm{mM}$ ), EtOH is considerably more potent in inhibiting responses to NMDA than in inhibiting responses to the glutamate receptor agonists kainate and quisqualate (14). In addition, voltage-clamp studies in our laboratory indicate that $\mathrm{EtOH}$ does not affect voltage-activated $\mathrm{Na}^{+}$or $\mathrm{Ca}^{2+}$ currents at concentrations between $\mathbf{5}$ and $100 \mathrm{mM}(15)$. These data, together with the fact that this concentration range of $\mathrm{EtOH}$ has not been reported to affect membrane ion currents in voltage-clamp experiments on mammalian neurons, suggest that $\mathrm{EtOH}$ at 5 to $100 \mathrm{~m} M$ does not alter ion channel function in a nonspecific manner (16). On the basis of biochemical studies showing EtOH potentiation of ${ }^{36} \mathrm{Cl}^{-}$flux, it has been suggested that $\mathrm{EtOH}$ may enhance $\mathrm{Cl}^{-}$current through channels activated by $\gamma$-aminobutyric acid (GABA) (17). However, electrophysiologic experiments examining EtOH effects on GABA-mediated responses have yielded conflicting results (18).

The concentration range over which EtOH inhibited the NMDA-activated current corresponds to the range over which intoxication occurs in nontolerant humans (19). For example, delayed reaction time and impairment of fine motor control can be detected at blood $\mathrm{EtOH}$ concentrations of 20 to $30 \mathrm{mg} / \mathrm{dl}$ (4 to $6 \mathrm{mM}$ ) (19). An increase in blood $\mathrm{EtOH}$ concentration from 20 to $30 \mathrm{mg} / \mathrm{dl}$ to 200 to $250 \mathrm{mg} / \mathrm{dl}$ (43 to $54 \mathrm{mM}$ ) results in increased impairment of mental ability and motor coordination that is generally recognized as increased intoxication (20). In our experiments, the threshold for inhibition of the NMDA-activated current was $\sim 5 \mathrm{mM}$, and increasing concentrations of $\mathrm{EtOH}$ produced increasing inhibition of the NMDA-activated current up to $50 \mathrm{mM}$. The observation that intoxicating concentrations of $\mathrm{EtOH}$ reduce the NMDAactivated current suggests that inhibition of responses generated by NMDA receptor acti- 
vation might contribute to intoxication.

When blood $\mathrm{EtOH}$ increases to concentrations greater than 200 to $250 \mathrm{mg} / \mathrm{dl}$, a second syndrome occurs that is characterized by progressive CNS depression and behavioral signs of general anesthesia such as increased sedation, stupor, and coma
(20). Because the inhibition of the NMDAinduced current by $100 \mathrm{mM} \mathrm{EtOH}$ was not significantly greater than the inhibition by $50 \mathrm{mM}$ EtOH, the general anesthetic effects of EtOH would not appear to result from EtOH inhibition of responses to NMDA. On the other hand, $\mathrm{EtOH}$ inhibition of the
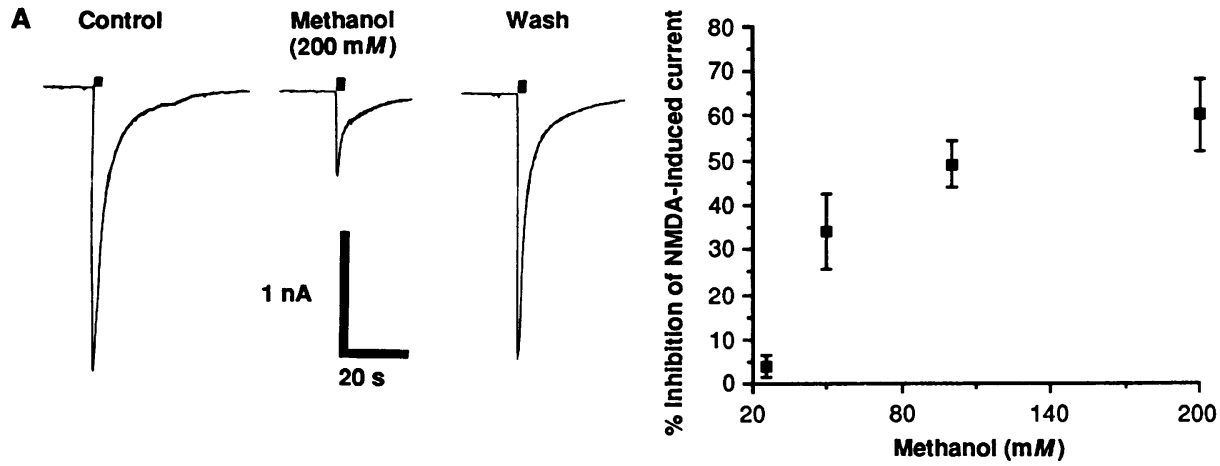

B
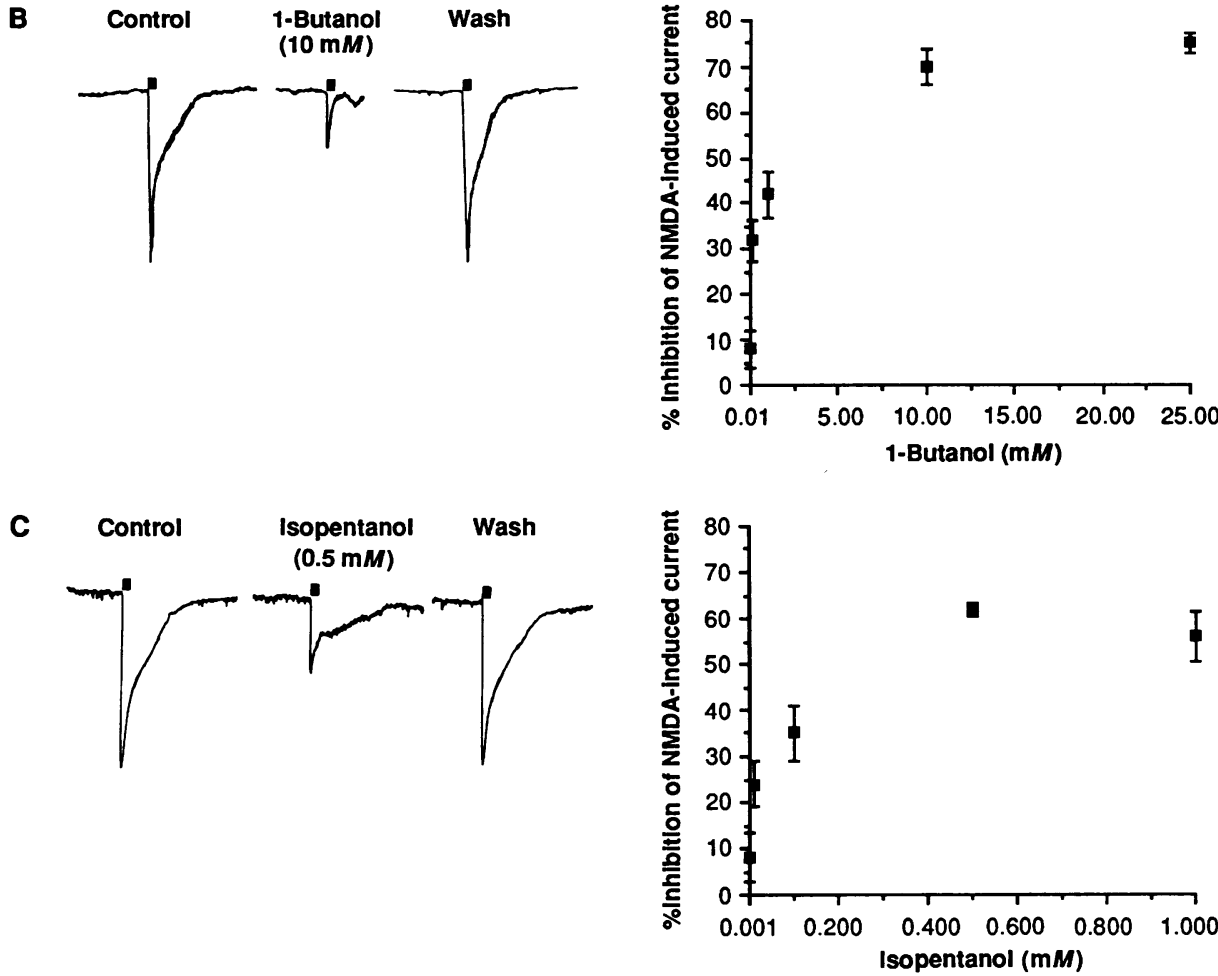

Fig. 2. Inhibition of NMDA-induced ion current by different alcohols. (A) (Left) Effect of methanol on current induced by NMDA application to a voltage-clamped hippocampal neuron. (Control) Inward current evoked by the application of $50 \mu M$ NMDA before methanol application. (Methanol) Current induced by $50 \mu M$ NMDA in the same cell during superfusion of the cell with $200 \mathrm{mM}$ methanol. (Wash) Current induced by application of $50 \mu M$ NMDA $2 \mathrm{~min}$ after termination of methanol application. (Right) Average percent inhibition of the NMDA-induced current as a function of methanol concentration. (B) (Left) Effect of 1-butanol on the NMDA-induced current. (Control) Current induced by $50 \mu M$ NMDA before 1-butanol application. (1-Butanol) Current induced by 50 $\mu M$ NMDA in the presence of $10 \mathrm{~m} M$ l-butanol. (Wash) Current induced by $50 \mu M$ NMDA 2 min after termination of butanol application. (Right) Average percent inhibition of the NMDA-induced current as a function of 1-butanol concentration. (C) (Left) Effect of isopentanol on NMDA-induced current. (Control) Current induced by $50 \mu M$ NMDA before isopentanol application. (Isopentanol) Current induced by $50 \mu M$ NMDA in the presence of $0.5 \mathrm{mM}$ isopentanol. (Wash) Current induced by $50 \mu M$ NMDA 4 min after termination of isopentanol application. (Right) Average percent inhibition of the NMDA-induced current as a function of isopentanol concentration. The concentration scales are different on the abscissa of each graph. Each point in the graphs represents the mean \pm SEM percent inhibition observed in at least four neurons tested at the indicated alcohol concentration. Records in (A), (B), and (C) are from different neurons. Time and current calibrations in (A) apply to all records. Membrane potential in all neurons was voltage-clamped at $-50 \mathrm{mV}$. currents produced by kainate and quisqualate increased substantially at EtOH concentrations greater than $50 \mathrm{mM}$. Because kainate and quisqualate receptors are thought to mediate fast synaptic transmission at glutamatergic synapses and glutamate is believed to be the major excitatory transmitter in the CNS, inhibition of kainate and quisqualate receptor-activated responses could result in general CNS depression. In sup-

A

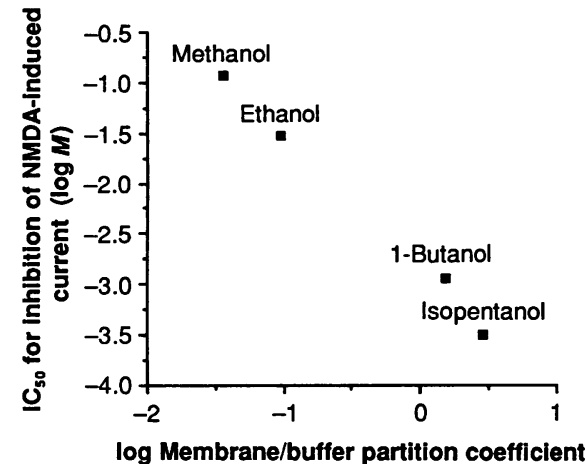

B

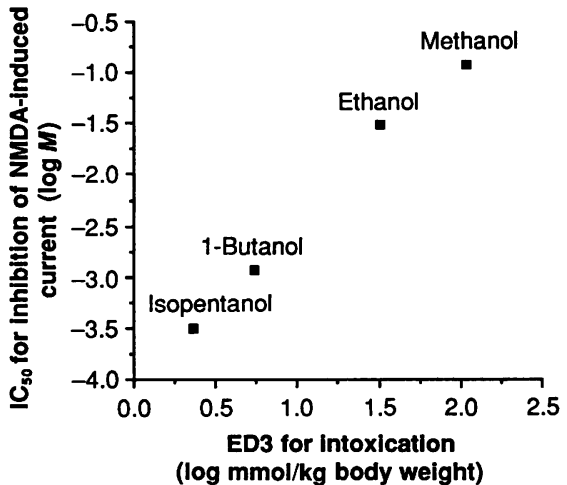

Fig. 3. Relation between the potency of different alcohols for inhibiting the NMDA-activated ion current, the hydrophobicity of the alcohols, and the potency of the alcohols for producing intoxication. (A) Log-log graph plotting the $\mathrm{IC}_{50}$ of the four alcohols tested for inhibition of the NMDAinduced current as a function of their membranebuffer partition coefficients (a measure of hydrophobicity). Membrane-buffer partition coefficient data are from (12). The linear relation between $\mathrm{IC}_{50}$ for inhibition of the NMDA-activated current and the membrane-buffer partition coefficient has a slope of $-1.30 \pm 0.055(P<0.01)$ (B) Log-log graph plotting ED3 for intoxication by the different alcohols versus the $\mathrm{IC}_{50}$ values for inhibition of the NMDA-induced current by the alcohols. ED3 for intoxication data are from (12). The linear relation between the $\mathrm{IC}_{50}$ for inhibition of the NMDA-induced current and the ED3 for intoxication has a slope of $1.579 \pm 0.099$ $(P<0.025)$. Probability level for the linear regression was determined with an analysis of variance (ANOVA). IC $_{50}$ values were determined by obtaining the best-fit curve over the linear portion of a $\log$ concentration-response plot for each of the alcohols and calculating by interpolation the alcohol concentration that would produce $50 \%$ inhibition of the NMDA-activated current. 
port of this notion, anesthetic barbiturates inhibit kainate- and quisqualate-induced responses more potently than they inhibit responses produced by NMDA receptor activation (21).

The mechanism by which alcohols inhibit the NMDA-activated ion current is not clear. It has previously been proposed that alcohol intoxication results from fluidization of neuronal membranes (13). The NMDA receptor-ionophore protein complex may be especially sensitive to changes in membrane fluidity, and net current flow through NMDA receptor-linked channels may decrease when fluidity increases. On the other hand, some investigators question whether membrane fluidization can account for the intoxicating actions of alcohols (22). Alternatively, alcohols could act on a hydrophobic region or regions of the NMDA receptor-ionophore complex or on a protein that affects the function of this complex. Whatever the mechanism, the correlation between the potency of different alcohols for inhibiting the response to NMDA and their potency for producing intoxication suggests that inhibition of responses generated by NMDA receptor activation may contribute to intoxication (23).

\section{REFERENCES AND NOTES}

1. W. R. Klemm, in Biochemistry and Phamacology of Ethanol, E. J. Majchrowitz and E. P. Noble, Eds. (Plenum, New York, 1979), vol. 2, pp. 243-267; W. A. Hunt, Alcohol and Biological Membranes (Guilford Press, New York, 1985), pp. 41-65; G. R. Siggins et al., Ann. N.Y. Acad. Sci. 492, 350 (1987).

2. D. R. Curtis, in Glutamic Acid: Advances in Biochemistry and Physiology, L. J. Filer, S. Garratini, M. R. Kare, W. A. Reynolds, Eds. (Raven Press, New York, 1979), pp. 163-175; P. J. Rogers, J. StormMathisen, G. A. R. Johnston, Eds., Glutamate: Transmitter in the Central Nervous System (Wiley, New York, 1981); J. C. Watkins and R. H. Evans, Annu. Rev. Pharmacol. Toxicol. 21, 165 (1981); A. C. Foster and G. E. Fagg, Brain Res. Rev. 7, 103 (1984); J. C. Watkins and H. J. Oliverman, Trends Neurosci. 10, 265 (1987).

3. R. Dingledine, M. A. Hyne, G. L. King, J. Physiol. (London) 380, 175 (1986); A. Stelzer, N. T. Slater, G. tenBruggencate, Nature 326, 698 (1987).

4. E. W. Harris, A. H. Ganong, C. W. Cotman, Brain Res. 323, 132 (1984); G. L. Collingridge and T. V. P. Bliss, Trends Neurosci. 10, 288 (1987); A. Kleinschmidt, M. F. Bear, W. Singer, Science 238, 355 (1987); J. A. Kauer, R. C. Malenka, R. A. Nicoll, Nature 334, 250 (1988).

5. R. G. M. Morris, E. Anderson, G. S. Lynch, M. Baudry, Nature 319, 774 (1986). In addition, the NMDA receptor-linked ion channel is blocked by psychoactive compounds such as phencyclidine (PCP) and ketamine [C. R. Honey, Z. Miljkovic, J. F. MacDonald, Neurosci. Lett. 61, 135 (1985); D. Lodge et al., in Excitatory Amino Acid Transmission, $\mathrm{T}$. P. Hicks, D. Lodge, H. McLennan, Eds. (Liss, New York, 1987), pp. 83-90; I. A. Kemp, A. C. Foster, E. H. F. Wong, Trends Neurosi. 10, 294 (1987)], suggesting that inhibition of responses to NMDA receptor activation may contribute to the cognitive impairment produced by these drugs.

6. W. Koek, E. Kleer, P. J. Mudar, J. H. Woods, Behav. Brain Res. 19, 257 (1986); D. A. Bennet and C. L. Amrick, in Excitatory Amino Acid Transmission, T. P. Hicks, D. Lodge, H. McLennan, Eds. (Liss, New York, 1987), pp. 213-216; K. A. O'Neill and
J. M. Liebman, Brain Res. 435, 371 (1987).

7. R. H. Evans, D. A. S. Smith, J. C. Watkins, J. Physiol. (London) 320, 55P (1981); M. L. Mayer and G. L. Westbrook, Prog. Neurobiol. 28, 197 (1987); A. B. MacDermott and N. Dale, Trends Neurosci. 10, 280 (1987).

8. A preliminary report of some of these results was presented at the Intemational Symposium on Alcohol and Seizures, Crystal City, VA, 29 to 30 September 1988.

9. Hippocampal neurons were dissociated from 16- to 17-day mouse embryos and grown in culture [I. D. Forsythe and G. L. Westbrook, J. Physiol. (London) 396, 515 (1988)]. Experiments were performed on neurons 2 to 4 weeks after plating. Whole-cell patchclamp recording with a List EPC-7 patch-clamp amplifier was performed at room temperature on neurons in culture dishes on the stage of an inverted phase-contrast microscope (Nikon Diaphot). Data were filtered (3-kHz cutoff frequency, 2-pole Bessel filter), displayed on a digital oscilloscope (Nicolet 2090-IIIA), and recorded with a pen recorder (Gould $2400 S$ or 2600 S, rise time $<4 \mathrm{~ms}$ ). Neurons were superfused at a rate of 1 to $2 \mathrm{ml}$ per minute with extracellular medium containing: $150 \mathrm{mM}$ $\mathrm{NaCl}, 5 \mathrm{mM} \mathrm{KCl}, 2.5 \mathrm{mM} \mathrm{CaCl}_{2}, 0$ or $1 \mathrm{mM}$ $\mathrm{MgCl}_{2}, 0.001 \mathrm{mM}$ tetrodotoxin (TTX), $10 \mathrm{mM}$ Hepes, and $10 \mathrm{mM}$ D-glucose; $p \mathrm{H}$ was adjusted to 7.4 with $\mathrm{NaOH}$ and osmolality to 340 mosmol with sucrose. When NMDA-activated currents were studied, $\mathrm{MgCl}_{2}$ was omitted from the extracellular medium to minimize voltage-dependent block of the NMDA-induced current by this ion [M. L. Mayer, G. L. Westbrook, P. B. Guthrie, Nature 325, 261 (1984); L. Nowak, P. Bregestovski, P. Ascher, A Herbet, A. Prochiantz, ibid. 307, 462 (1984)]. Kainate and quisqualate-activated currents were studied in an extracellular medium containing $1 \mathrm{mM}$ $\mathrm{Mg}^{2+}$ and $50 \mu M$ D,L 2-amino-5-phosphono valeric acid (APV) (to prevent activation of NMDA receptor-mediated currents). In all experiments, the patch-pipette (intracellular) solution contained 140 $\mathrm{m} M \mathrm{CsCl}, 2 \mathrm{mM} \mathrm{MgCl}$, $1 \mathrm{mM} \mathrm{CaCl}, 11 \mathrm{mM}$

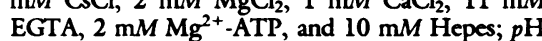
was adjusted to 7.4 with $\mathrm{CsOH}$ and osmolality to 310 mosmol with sucrose. Patch pipette filled with internal solution had tip resistances of 3 to $4 \mathrm{meg}$. ohm. Glutamate receptor agonists were applied from a large-bore pipette ( $>40 \mu M$ tip diameter) placed within three cell diameters of the soma of the neuron under study. When the effects of alcohols were examined, the alcohols were placed in largebore pipettes containing glutamate receptor agonist and the two compounds were delivered simultaneously to the neuron. All neurons used in this study had resting potentials (potentials observed when 0 current was applied in current-clamp recordings) greater than $-50 \mathrm{mV}$ on the initiation of whole-cel patch-clamp recording. Series resistance compensation of 40 to $60 \%$ was applied during all recordings. Averages in the text are mean $\pm S E M$.

10. The NMDA concentration used in all experiments in this report was $50 \mu M$. Similar inhibition of the NMDA-activated current by EtOH was observed when the NMDA concentration was $10 \mu M$ $(n=3)$. We have observed inhibition of NMDAactivated current by $\mathrm{EtOH}$ over a similar concentration range in cultured mouse spinal cord neurons and acutely isolated adult rat dorsal root ganglion neurons. The effect of EtOH on the NMDA-activated current might result from effects of EtOH on membrane properties other than those involved in the NMDA response. We found, however, that application of $100 \mathrm{mM} \mathrm{EtOH}$ alone did not activate a transient current or change the steady-state current at a given membrane potential. In addition, the administration of $100 \mathrm{mM} \mathrm{EtOH}$ did not alter the input resistance as measured in voltage-clamp by holding the membrane potential at $-50 \mathrm{mV}$ and stepping in $5-\mathrm{mV}$ increments to potentials in the range -80 to $-55 \mathrm{mV}$. The input resistance was calculated from the slope of the current-voltage ( $I$ $V$ relationship. It thus seems unlikely that the effect of EtOH on the NMDA-induced current results from nonspecific membrane actions or from changes in the whole-cell recording conditions, such as an alteration in the electrode-cell seal resistance.

11. L. J. Mullins, Chem. Rev. 54, 289 (1954); R. C
Lyon, J. A. McComb, J. Schreurs, D. B. Goldstein J. Phamacol. Exp. Ther. 218, 669 (1981).

12. M. J. McCreery and W. A. Hunt, Neuropharmacology. 17,451 (1978).

13. J. H. Chin and D. B. Goldstein, Mol. Pharmacol. 13, 435 (1977); D. B. Goldstein, Annu. Rev. Pharmacol. Toxicol. 24, 43 (1984).

14. Ethanol prevents the initiation of long-term potentiation (LTP) of synaptic responses in hippocampus [J. G. Sinclair and G. F. Lo, Gen. Pharmacol. 17, 231 (1986); D. Mulkeen, R. Anwyl, M. J. Rowan, Neurosci. Lett. 80, 351 (1987)] and NMDA-receptor activation is crucial for the initiation of LTP (4).

15. S. R. Ikeda et al., unpublished observations.

16. Although acute EtOH exposure alters the activity of neural enzymes including receptor-stimulated adenylate cyclase and $\mathrm{Na}^{+}-\mathrm{K}^{+}$ATPase, little or no effect has been observed at EtOH concentrations of $\mathbf{5 0}$ $\mathrm{mM}$ or below [W. A. Hunt, Alcohol and Biological Membranes (Guilford Press, New York, 1985), pp. 81-99]. In contrast, the inhibition of the NMDAactivated current is near maximal at $50 \mathrm{mM}$ EtOH.

17. P. D. Suzdak, R. D. Schwartz, P. Skolnick, S. M Paul, Proc. Natl. Acad. Sci. U.S.A. 83, 4071 (1986); A. M. Allan and R. A. Harris, Life Sci. 39, 2005 (1986); A. K. Mehton and M. K. Ticku, J. Phamacol. Exp. Ther. 246, 558 (1988)

18. EtOH potentiates GABA-mediated inhibition of single unit responses in cat cortex [J. N. Nestoros, Science 209, 708 (1980)]. However, EtOH does not appear to affect GABA-mediated inhibition of unit responses [J. R. Mancillas, G. R. Siggins, F. E. Bloom, Science 231, 161 (1986)] or GABA-mediated inhibitory synaptic potentials [G. R. Siggins, Q J. Pittman, E. D. French, Brain Res. 414, 22 (1987)] in hippocampus. It has also been reported that 10-s but not 30-s applications of $\mathrm{EtOH}$ can potentiate GABA-activated current in voltage-clamped chick spinal cord neurons [J. J. Celentano, T. T. Gibbs, D. H. Farb, Brain Res. 455, 377 (1988)]. However, no effects of EtOH on GABA-activated $\mathrm{Cl}^{-}$current have been observed in voltage-clamp experiments on neurons from adult rat dorsal root ganglia [G. White and F. F. Weight, Int. Symp. Alcohol Seizures Abstr., p. 24 (1988)], rat spinal cord [J. L. Barker, N. L. Harrison, G. D. Lange, D. G. Owen, J. Physiol. (London) 386, 485 (1987)] or rat hippocampus [N. L. Harrison, M. D. Majewska, J. W. Harrington, J. L. Barker, J. Pharmacol. Exp. Ther. 241, 346 (1987); S. Huck, R. Gratzel, F. Grissmayer, Soc. Neurosci. Abstr. 13, 65 (1987)]

19. M. A. Schuckit, Drug and Alcohol Abuse (Plenum, New York, 1979), pp. 42-44; J. M. Ritchie, in The Pharmacological Basis of Therapeutics, A. G. Goodman, L. S. Gilman, T. W. Rall, F. Murad, Eds. (Macmillan, New York, 1985), pp. 372-373

20. B. Kissin, in Cecil Textbook of Medicine, J. B. Wyngaarden and L. H. Smith, Eds. (Saunders, Philadelphia, PA, 1988), pp. 48-51.

21. N. L. Harrison, J. Physiol. (London) 360, 38P (1985); Z. Miljkovic and J. F. MacDonald, Brain Res. 376, 396 (1986). This observation also indicates that the NMDA receptor-ionophore complex is not uniquely sensitive to CNS depressants.

22. R. A. Deitrich, in Recent Developments in Alcoholism M. Galanter, Ed. (Plenum, New York, 1987), vol. 5 pp. 283-287; S. Treistman and A. Wilson, Proc. Natl. Acad. Sci. U.S.A. 84, 9299 (1987); G. F Koob and F. E. Bloom, Science 242, 715 (1988).

23. In this regard, intracerebroventricular injection of APV, a specific NMDA receptor antagonist, produces behavioral changes similar to those observed during $\mathrm{EtOH}$ intoxication [J. H. Woods, W. Koek, P. Ornstein, in Excitatory Amino Acid Transmission, $\mathrm{T}$ P. Hicks, D. Lodge, H. McLennan, Eds. (Liss, New York, 1987), Pp. 205-212].

24. We thank P. G. Nelson, M. L. Mayer, and S Fitzgerald for generously providing cultured hippocampal neurons. We also thank L. G. Aguayo for helpful advice on whole-cell patch-clamp recording and for critical comments on the manuscript, and $\mathrm{P}$. L. Hoffman and C. S. Rabe for providing methanol 1-butanol, and isopentanol. D.M.L. was supported in part, by an Intramural Research Training Award from National Institute of Neurological Disease and Stroke.

7 December 1988; accepted 23 January 1989 